\title{
SUSTAINABLE MANAGEMENT OF BIOMASS ENERGY IN RURAL AND URBAN CONTEXT \\ ${ }^{1}$ J. Szendrei, ${ }^{2}$ E. Szǘcs, ${ }^{3}$ G. Grasselli \\ ${ }^{1}$ University of Debrecen, Faculty of Engineering, Otemetö u. 2-4, 4028 Debrecen, Hungary e-mail: szendrei.janos@eng.unideb.hu
}

\begin{abstract}
The most sustainable energy is the energy not used. Best way to (not) use energy is the proper design of a facility or an energy consuming system. The remaining energy needs have to be covered with energy utilisation of waste materials, renewable energy sources and, until the previous solutions are not sufficient to satisfy the energy demands, the last is the use of conventional fossil and nuclear energy sources. In terms of renewable energy, biomass has an important role today. However, there is a difference between available inputs and utilisation when considering biomass energy possibilities in rural and urban context. This paper suggests biomass energy possibilities that are recommendable in rural context: possibilities of solid biomass combustion, of liquid biofuels and of anaerobe digestion. Also important are possibilities of solid biomass combustion and wet biomass digestion for urban energy production, although with some remarks on system considerations of urban biomass. Most advanced solutions for sustainable management of biomass energy include circular systems, both in rural and urban context, as recommended
\end{abstract}

Keywords: biomass, energy, sustainable, urban, rural, circular economy

\section{INTRODUCTION}

Energy not used is the cheapest energy is - this attitude can serve as the basis for planning a sustainable energy supply of a region, production facility or consumer [4]. The energetic planning and its implementation are very important in case of a facility, which is supported also by EU and domestic regulation [14]. This is closely followed by energy utilisation of waste materials [5]. Then, the use of renewable energy sources follows, to the sustainable extent. The last is the use of conventional fossil and nuclear energy sources, until their replacement is solved in ab economically efficient and sustainable way. This paper aims to suggest possibilities for sustainable biomass energy production in rural and urban areas. By using biomass and wastes, and through the technologies of circular economy, energetic self-sufficiency is reachable [10].

\section{MATERIALS AND METHODS}

The methodology used in the elaboration of this paper was to collect, process and suggest possibilities on the sustainable management of biomass energy, both in rural and urban areas. Materials used are the publications listed among the references used in this paper.

\section{RESULTS AND DISCUSSION}

\subsection{Biomass energy in rural context}

\section{Possibilities of solid biomass combustion for rural energy production}

A small biomass-based CHP with ca. 2 MW electric output (and with ca. 4 MW thermal output) can be applied to cover the heat demand of a small settlement or a settlement centre (Fig. 1), at the same time producing electricity, which is universally (grid) marketable. 


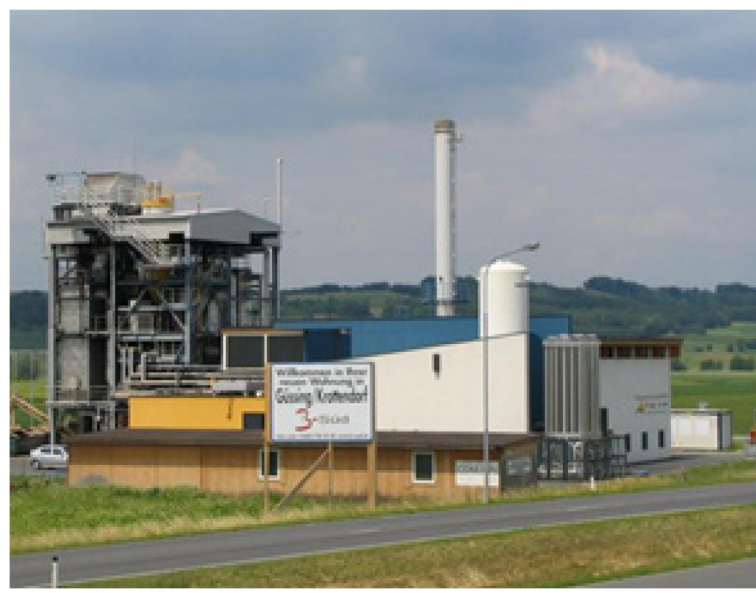

Figure 1. A 2 MW wood-chips power plant in Güssing, Austria (ca. 3000 inhabitants) [6]

According to our calculations [6], with ca. 1.2 billion HUF investment this type of a wood chips based power plant can be established within 2 years, paired with a discounted payback period (DPP) of 5.6 years in case of at least $80 \%$ heat utilization and no financial support, and with 1.2 years in case of an additional $50 \%$ investment support. The employment increase amounts to 350 people including the 20 people serving the power plant. The energy plantations need 1400 ha area.

\section{Possibilities of liquid biofuels for rural energy production}

Biofuels are made from rural biomass. A good example is ethanol, nowadays mainly produced out of corn in Hungary. The main capacities are owned by Hungrana Ltd., which is processing around one tenth of the yearly domestic corn production (Fig. 2).

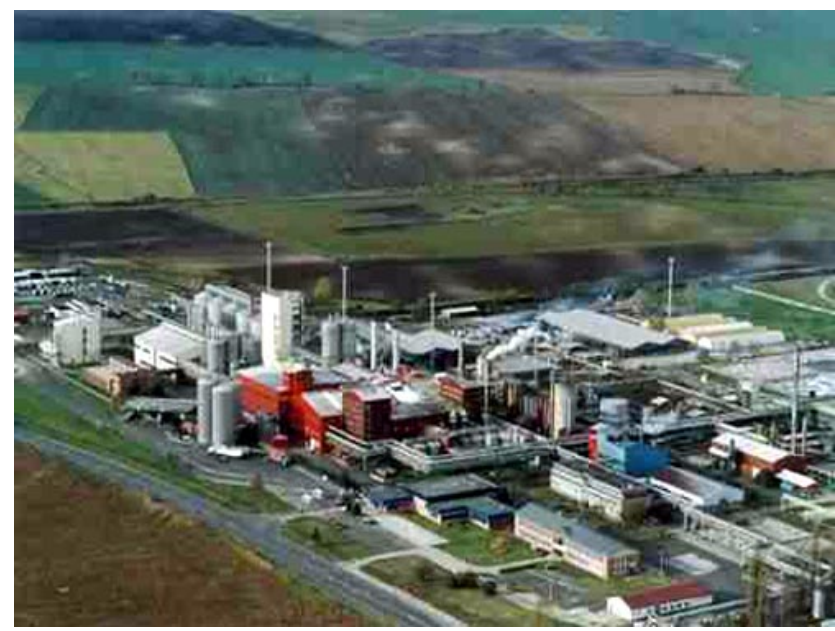

Figure 2. Hungrana facilities producing ethanol [7]

Hungarana Ltd. is one of the largest maize processors in Europe. The facility processes corn into corn starch and isoglucose for the food processing industry as well as bioethanol for the petrochemical industry. The company is proud to be a bioeconomy company, that is, to make natural products exclusively by 
natural means, using a broad range of the most modern technologies and renewable energies, without waste. Because of the changes in the sugar market and the growing demand for biofuels, the company has tripled its bioethanol production capacity in an expansion project completed in July 2008. Today the plant produces around 150,000 $\mathrm{t}$ of bioethanol per year, by processing over one million tonnes of corn [7].

\section{Possibilities of anaerobe digestion for rural energy production}

In our former investigations [3], six models with different sizes were examined for heat production and cogeneration. Among these, models $1-5^{\text {th }}$ were based on an input mixture of two-third pig and cattle manure and one-third silage, with $16 \%$ dry matter content. The $6^{\text {th }}$ model is based on approx. $50 \%$ liquid manure, one-third manure with litter, and the rest made up mainly of corn silage, with $15 \%$ dry matter. The $1^{\text {st }}$ and $3^{\text {rd }}$ models are based on actual German plants' data, the $2^{\text {nd }}, 4^{\text {th }}$ and $5^{\text {th }}$ on average of German plants' data, whereas the $6^{\text {th }}$ model on the data of one of our newest reference plant. The latter model uses twophase (mesophilic + thermophilic) digestion, while the smaller plants use one-phase mesophilic technology. The small plants $\left(1^{\text {st }}, 2^{\text {nd }}\right.$ model $)$ use Diesel engines with fuel injection, the electric efficacy of which is $4-5 \%$ lesser than that of the Otto-engines used at the larger plants ( $3^{\text {rd }}-6^{\text {th }}$ models $)$; moreover, their diesel oil demand is also considerable. The key operational and economic base data of the models investigated are described in Tab. 1. The very good values of model 3 are perhaps describing the achievable optimum (proper mixture, proper sizing).

Table 1. Biogas Plant Models for Heat Generation and Cogeneration [3]

\begin{tabular}{|c|c|c|c|c|c|c|}
\hline Model & 1 & 2 & 3 & 4 & 5 & 6 \\
\hline Input, t/year & 3182 & 4952 & 17411 & 23968 & 47936 & 90255 \\
\hline Volume of Digester, gross $\mathrm{m}^{3}$ & 420 & 750 & 2400 & 3000 & 5500 & 8000 \\
\hline CHP, $\mathbf{k W}_{\mathrm{el}}$ & 55 & 100 & 330 & 500 & 1000 & 1672 \\
\hline Bio-manure Storage, $\mathrm{m}^{3}$ & 410 & 410 & 1700 & 2770 & 2770 & 2770 \\
\hline Temperature of Digestion & \multicolumn{5}{|c|}{ mesophilic } & $M+T^{*}$ \\
\hline Investment costs, M HUF & 61 & 137 & 191 & 495 & 908 & 1400 \\
\hline
\end{tabular}

In the different size categories, biogas investment can be facilitated economically even under present macro-economic conditions, though using different technological solutions. In small-sized plants, heat energy utilization is to be considered (preferably to cover own demands), because of the lesser electric efficacy and extra material costs, and extra investment costs of cogeneration. This can be an alternative to natural gas firing even under present price conditions, especially when the biogas investment is weighed strategically, together with its complex (environmental, employment-assuring) benefits. In middle sized and large plants the own consumption is not realizable because of the greater quantity, therefore, cogeneration production of electricity is advised, under partial or full heat utilization (Fig. 2). Under worsening Hungarian conditions of "green" electricity take-over, the transformation of biogas to another marketable product, bio-methane, is to be considered. This involves no waste-heat generation, the utilization of which is always a critical point of operating cogeneration. Based on waste materials, or, perhaps, also with utilization of the carbon-dioxide from purification, in large plant sizes this can mean a profitable way of green energy production 


\subsection{Biomass energy in urban context}

Biomass from urban spaces, as compared to rural biomass, consists mainly of municipal and industrial wastes and wastewater, and to a smaller extent, of biomass residues from maintenance of green areas.

\section{Possibilities of solid biomass combustion for urban energy production}

As regards the energy use of the constantly re-generated municipal solid waste and its considerable biomass (carbon) share, waste incineration plants can provide a solution. As a study highlights, waste utilization and waste prevention should contradict each other [15]. Countries that have high waste incineration rates also achieve the highest recycling rates, e.g. the Netherlands, Switzerland, Austria, Germany and the Scandinavian countries. Common base feature of their policies is that they have sharply restricted or even banned landfill as a cheap disposal route, for example by taxes, or prohibiting legislation. Whereas waste reduction is a matter of material efficiency of manufacturing and of altering of consumer behaviour favouring products including less waste within their life cycle, waste incineration remains an important tool for disposal security and energy recovery in a recycling economy based on material and resource efficiency.

Linköping has an existing waste incineration plant (Fig. 3) with a capacity of 250,000 tonnes of waste a year and is investing in order to increase the capacity to 350,000 tonnes of waste a year. The base supplier of heat is the waste incineration plant with a total capacity of $70 \mathrm{MW}$ and an additional $10 \mathrm{MW}$ from flue gas condensing. Electricity can also be produced by a steam turbine integrated with an oil-fired gas turbine, a so-called hybrid system. The hybrid system has a capacity of $47 \mathrm{MW}_{\mathrm{el}}$ [7].

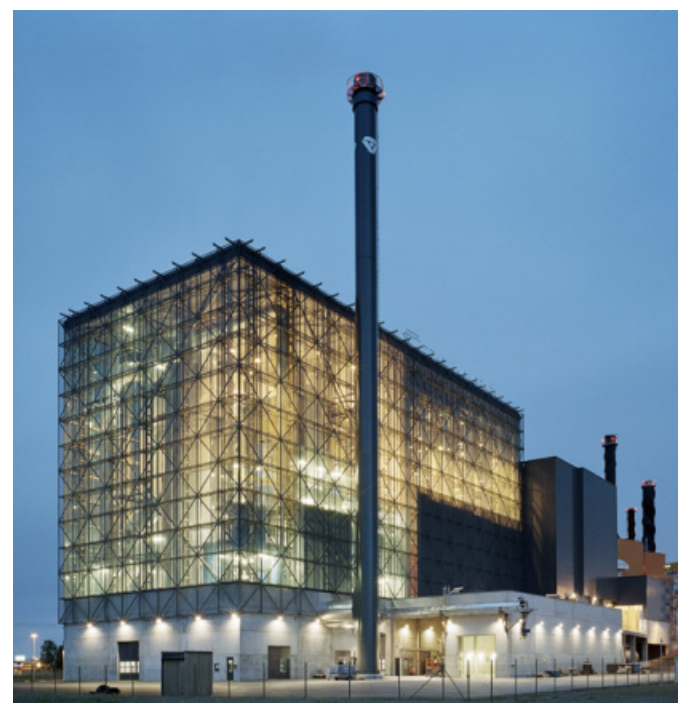

Figure 3. The now 80 MW capacity Linköping waste incineration plant [11]

\section{Possibilities of wet biomass digestion for urban energy production}

Wastewaters and easily biodegradable food residues as well as green plant material (e. g. grass clippings) can be used as substrate for anaerobe digestion. When converted into biogas production, these can serve even as vehicle fuel. A former study investigating the local possibilities of biogas as fuel for public transport has evaluated the local sources of biogas, the sewage treatment plant and the landfill gas from the waste disposal site with the result that both are principally good for vehicle fuel (although used for other purposes). The advantages and disadvantages of biogas from different sources were summarized in the 
Tab. 2 from [1]. An example of biogas production can be the biogas plant in Linköping, using organic food wastes from the town and also additives from neighbouring agricultural producers (Fig. 4.).

Table 2. Biogas Plant Models for Heat Generation and Cogeneration [1]

\begin{tabular}{|l|l|l|l|l|}
\hline \multirow{2}{*}{$\begin{array}{l}\text { Biogas } \\
\text { possibilities }\end{array}$} & \multicolumn{2}{|l|}{ Sewage plant } & Firm waste disposal site \\
\cline { 2 - 5 } & Advantage & Disadvantage & Advantage & Disadvantage \\
\hline Amount & $2,2 \mathrm{M} \mathrm{m}^{3}$ & & & $0,7 \mathrm{M} \mathrm{m}^{3}$ \\
\hline Quality & $60-65 \% \mathrm{CH}_{4}$ & $360 \mathrm{mg} \mathrm{S} / \mathrm{m}^{3}$ & $1-2 \mathrm{ppm} \mathrm{H}_{2} \mathrm{~S}$ & $45-48 \% \mathrm{CH}_{4}$ \\
\hline Remark & Available locally & $\begin{array}{l}\text { Used for own } \\
\text { electricity supply }\end{array}$ & $\begin{array}{l}\text { Available locally. } \\
\text { Surplus at low price. }\end{array}$ & $\begin{array}{l}\text { Ownership of } \\
\text { utilization rights. }\end{array}$ \\
\hline
\end{tabular}

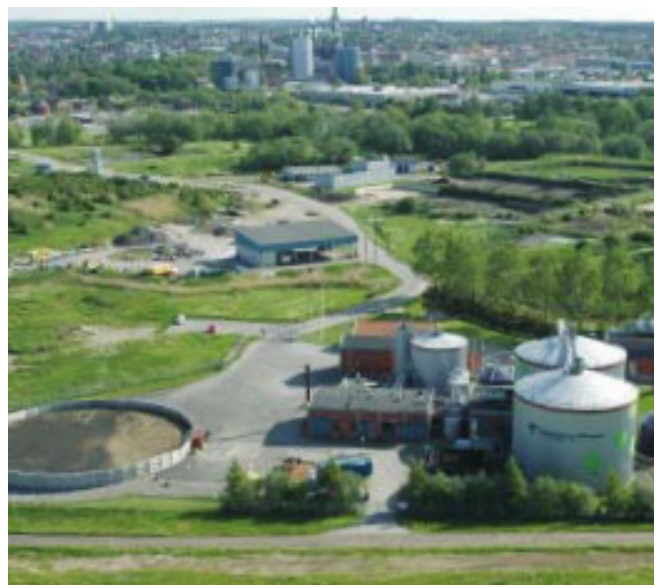

Figure 4. Biogas plant in Linköping, based mainly on municipal wet organic wastes [17]

\section{Urban biomass as energy source: system considerations}

Of course, distinction should be made in terms of nature and quantity of waste generated in case of the utilization of urban waste, as well. Family housing areas of the cities produce bio-waste that is less dangerous to the environment than the wastes of processing industry or slurry from large-scale animal husbandry, remarkably because wastes are generated not at a single point, in large amounts, but rather scattered in space. A study using GIS methods confirms [11] that compost use of detached houses' organic wastes may be recommended, involving less cost than small-scale, household-sized biogas production. The power management of the settlement is helped by this solution by the lesser quantities of waste to be removed, so that transport energy demand used in waste logistics will be smaller.

\subsection{Sustainable management of biomass energy in rural and urban context}

\section{A sustainable, farm-scale closed-circuit biomass energy system for rural areas}

Combining pathways of bioenergy production can lead to closed cycle material flow, as in the example of a combined ethanol and biogas production system elaborated by [9] (Fig. 5.). Within this system, the distillation residue of alcohol production serves as an additive for biogas production. In turn, the surplus heat of biogas-based co-generation can supply the heat demands of alcohol production. The digested manure and alcohol fermentation residues can be used for enhancing soil fertility for biomass production, while the produced electric power together with surplus heat can be commercialized. 


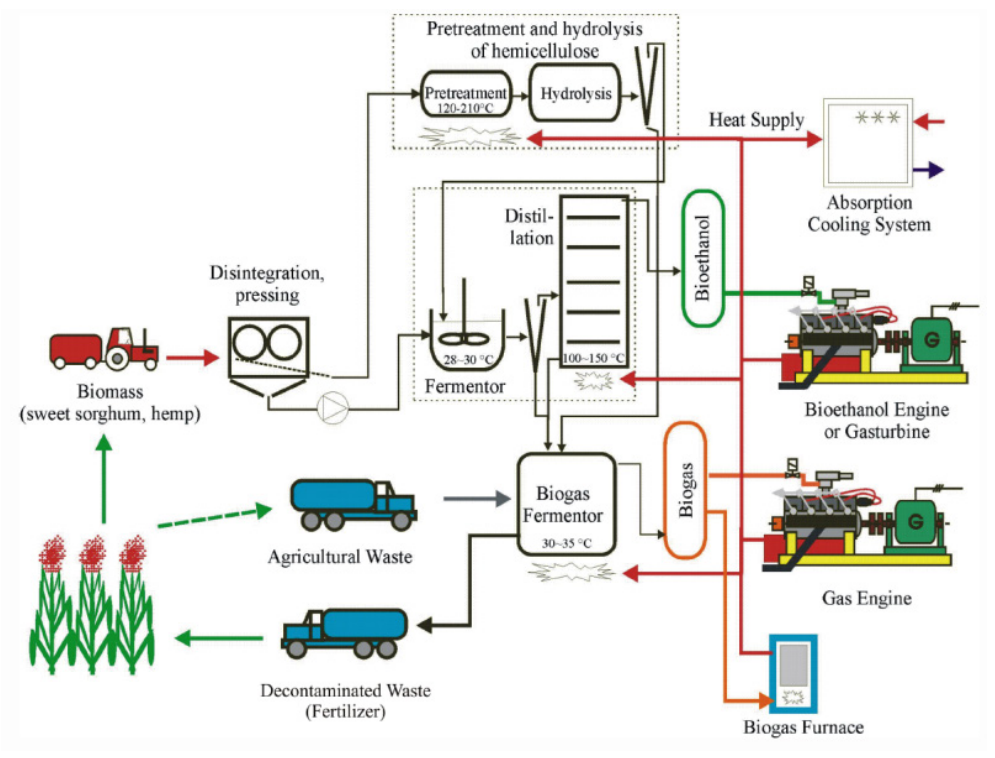

Figure 5. Example of a combined ethanol and biogas production system [9]

\section{Complex circular systems at large - the Östergötland case: a biomass-based complex regional ecosystem including urban areas}

After considering a farm-scale closed-circuit system, it is useful to consider an already established largescale case of circular economy, that of the Östergötland region in the southern part of Sweden.

First, a commonly accepted (Wikipedia) definition for circular economy should be cited here:

"The circular economy is a generic term for an industrial economy that is, by design or intention, restorative and in which materials flows are of two types, biological nutrients, designed to re-enter the biosphere safely, and technical nutrients, which are designed to circulate at high quality without entering the biosphere." [16]

This definition focuses on biomass and its constituents as "biological nutrients" - however, on the energy side, these are coupled with usage forms of biomass energy. The system of the "circular economy", as shown on Fig. 6, consists of more than 100 environmental technology companies, managed by a system operator company, which is a joint venture of these companies overseen by the involved communities and the local university. Managing, maintaining and developing such a large technical system is a real challenge towards sustainable management of locally available biomass resources [12].

The energy supply of the cities Linköping and Norrköping is based on Waste to Energy solutions that are based on local biomass. The combined heat and power plants (waste-incinerating plants) utilize the waste of these cities, tri-generating energy for these cities in the form of district heating, district cooling, and electricity. Other utilizers of urban biomass are wastewater treatment plants, using communal and industrial wastewater and thus producing biogas for tri-generation in biogas plants and as vehicle fuel into the biogas distribution net. Other biomass energy solutions in the system are the ethanol and biodiesel production facilities. These material and energy flows are based on the local agricultural sector: agriculture provides the crops and livestock for the local food industry and through the restaurants the waste oil for biodiesel production, and the grain for the ethanol plant. As a closing (or starting) point in the circle, agriculture also takes up the end-products of the processes as livestock feed and biofertilizer. 


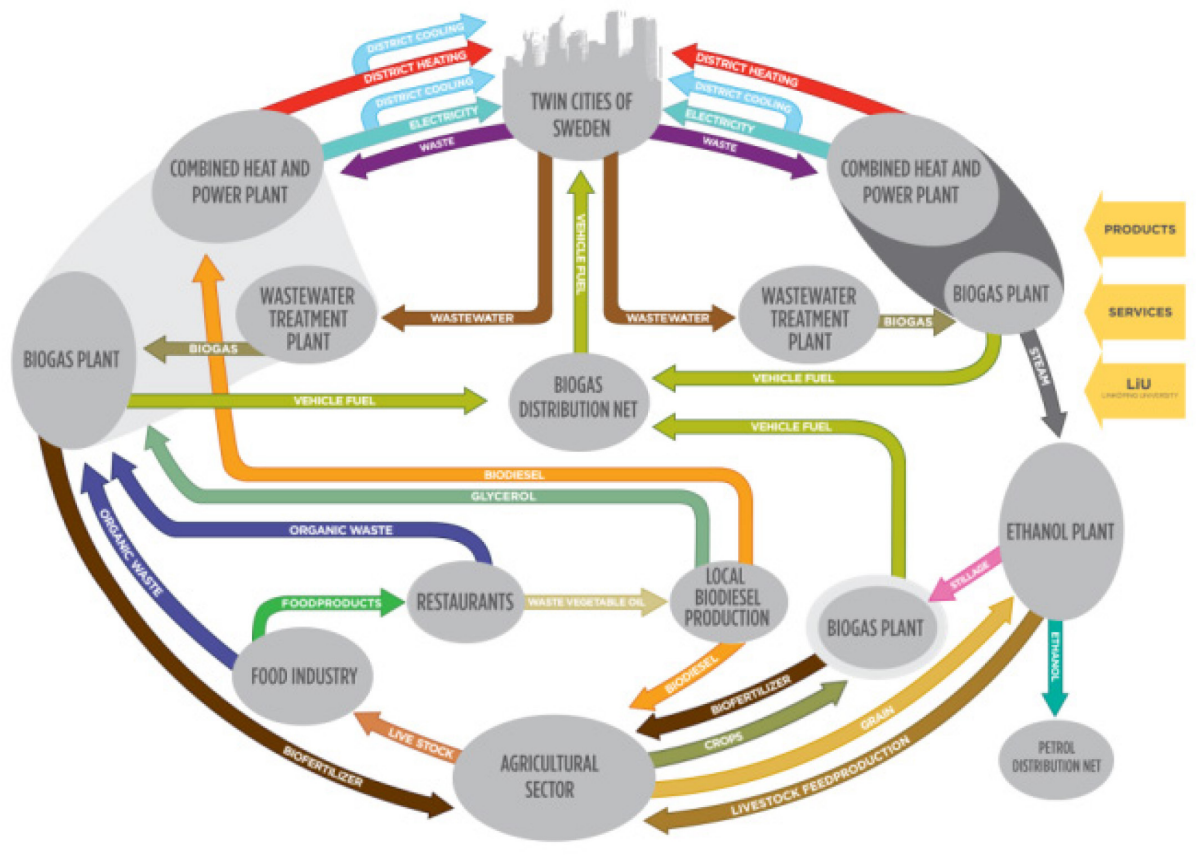

Figure 6. Circular economy in Östergötland, Sweden [1]

An investigation of the system says that "the strong link between the industry, government and academia with respect to innovative approaches for applying renewable energy and industrial symbiosis plays a strong role at the macro level in the Östergötland community" [1].

\section{CONCLUSIONS}

Considering the possibilities of both rural and urban areas in bioenergy production, the conclusion can be drawn that bioenergy has a firm place among sustainable solutions for energy supply, supported with proper management.

The adequate way of biomass energy production is decentralised energy supply, as this is the optimum use of combined heat and power generation from both solid and wet biomass. In rural context, heat can be used to power production facilities, or supply the needs of smaller settlements. In urban context, municipal solid wastes and wastewater can serve as the basis for cogeneration (trigeneration).

As regards liquid biofuel production, ethanol is produced from rural resources, that is, corn produced on arable land. This is better conducted in a system that also includes other bioenergy routes as well, as in case of a combined ethanol and biogas production system. This provides a closed-circuit material management, at the same time producing renewable energy in a sustainable way.

Perhaps the most complex and more promising example of possible biomass energy solutions is the case considered in the regional biomass-utilization and waste management system of Östergötland. This covers both urban and rural solutions, connecting them to a network of technologies serving sustainable materialand energy management. 


\section{REFERENCES}

[1] L. Baas, Östergötland: Towards a sustainable region on the basis of industrial symbiosis and renewable energy, $16^{\text {th }}$ Annual International Sustainable Development Research Conference, Hong Kong, May 30 - June 1, 2010. http://www.diva-portal.org/smash/get/diva2:464808/FULLTEXT01.pdf

[2] A. Bai, A. G. Grasselli, Sz. Kormányos, J. Szendrei, Future use of biogas in Debrecen - possibilities in public transport, Waste to Energy Conference, Jyväskylä, 14-17. September 2005.

[3] A. Bai, G. Grasselli, J. Szendrei, Sz. Kormányos, Economic Evaluation of Scaling of Agricultural Biogas Plants, Hungarian Agricultural Engineering, No. 20/2007, p. 23-25. HU ISSN 0864-7410

[4] T. Balla, A. Halczman, I. Kocsis, A. Matkó, E. Szücs, J. T Kiss, E. Varga, Energiahatékonyság költséghatékonyság (Energy efficiency - cost efficiency), in: F. Kalmár (ed.): Fenntartható energetika megújuló energiaforrások optimalizált integrálásával (Sustainable energy through optimized integration of renewable energy sources). 403 p. Budapest: Akadémiai Kiadó, 2014. pp. 301-336. ISBN:978963059540 7

[5] I. Budai, Hulladékok és megújítható nyersanyagok hasznosítási lehetőségei (Utilization possibilities of wastes and renewable raw materials), Debreceni Egyetem, 2014. 123p. ISBN 978-963-473-792-6

[6] G. Grasselli, A. Bai, J. Szendrei, Biomassza-erőmüvek energetikai, gazdasági és vidékfejlesztési hasznai (Energy, economy and rural development uses of biomass power plants), Mezőhír, Vol. X. No. 9. pp. 98-99. HU ISSN 1587-060X September 2006.

[7] K. Holmgren, D. Henning, Comparison between material and energy recovery of municipal waste from an energy perspective: A study of two Swedish municipalities,. Resources, Conservation and Recycling, Volume 43, Issue 1, December 2004, pp. 51-73

[8] Hungrana - Maize Processing Plant Expansion, Hungary. foodprocessing-technology.com, http://www.foodprocessing-technology.com/projects/hungrana/

[9] I. Kalmár, V. E. Kalmárné, V. Nagy, L. Sikolya, Using remnants of alcohol distillery for biogas production in frame of a pilot project in Hungary, Nonconventional Technologies Review (2014-) XVIII:(2) pp. 23-26. (2014) http://www.revtn.ro/pdf2-2014/Kalmar_Karmarne_Nagy_Sikolya.pdf

[10]B. Kulcsár, Önellátó települések 1. Települések energetikai önfenntartásának alapjai (Self-sustaining communities I. Basis of energetic self-sufficiency of settlements), Debreceni Egyetem, 2014. 94p. Debreceni Egyetem. ISBN 978-963-473-793-3

[11]Linköping - Food waste powers public transport, http://www.symbiocity.org/en/approach/Casesundersidor/Linkoping-waste-not-want-not/

[12]M. Martin, The "Biogasification" of Linköping : A Large Technical Systems Perspective, Report, 2009. http://liu.diva-portal.org/smash/get/diva2:275703/FULLTEXT02

[13]F. Szabó, A. Matkó, N. Boros, A háztartásokban keletkező biológiailag bontható szerves hulladék és szennyvíziszap hasznosításának lehetőségei biogáz és komposzt előállítására (Utilization possibilities of biodegradable organic waste and sewadge sludge for compost and biogas production), DEBRECENI MÜSZAKI KÖZLEMÉNYEK 13:(1) pp. 1-17. (2014) http://eng.unideb.hu/dmk/docs/20141/szabo\%20fruzsi.pdf

[14] J. T. Kiss, I. Kocsis, On the optimization of energy-efficient modernization and renewable energy investments, ANNALS OF THE ORADEA UNIVERSITY Fascicle of Management and Technological Engineering ISSUE \#1, MAY 2013. pp. 155-158. http://imtuoradea.ro/conf/2013/Kiss\%20Judit\%202.pdf

[15] Waste Incineration and Waste Prevention: Not a Contradiction in Terms, Umweltbundesamt (German Federal Environment Agency) Press Office, Dessau, July 2008.

[16]Wikipedia article on Circular economy, http://en.wikipedia.org/wiki/Circular_economy

[17] 100\% Biogas for urban transport in Linköping, Sweden. Biogas in buses, cars and trains. BIOGAS IN THE SOCIETY - Information from IEA BIOENERGY TASK 37 Energy from biogas and landfill gas. (2005) http://www.seai.ie/Renewables/Bioenergy/100_biogas_for_urban_transport_in_Linkoeping_IEA_Bio_ Task_37.pdf 